\title{
Characterization of a prolidase from Lactobacillus delbrueckii subsp. bulgaricus CNRZ 397 with an unusual regulation of biosynthesis
}

\author{
Fabienne Morel, Jacques Frot-Coutaz, Dominique Aubel, \\ Raymond Portalier and Danièle Atlan
}

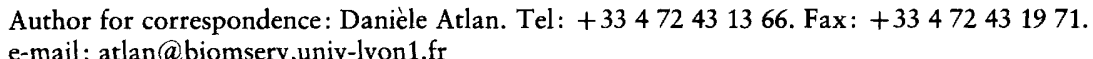

Laboratoire de

Microbiologie et Génétique

Moléculaire, UMR CNRS

5534, Université Claude

Bernard, Lyon I, F-69622

Villeurbanne cedex, France

\begin{abstract}
Lactobacillus delbrueckii subsp. bulgaricus CNRZ 397 (Lb. bulgaricus) is characterized by a high level of peptidase activities specific to prolinecontaining peptides. A prolidase (PepQ, EC 3.4.13.9) was purified to homogeneity and characterized as a strict dipeptidase active on X-Pro dipeptides, except Gly-Pro and Pro-Pro. The values for $\boldsymbol{K}_{m}$ and $\boldsymbol{V}_{\max }$ were, respectively, $2.2 \mathrm{mM}$ and $0.33 \mathrm{mmol} \mathrm{min}^{-1} \mathrm{mg}^{-1}$, with Leu-Pro as the substrate. The enzyme exhibited optimal activity at $50^{\circ} \mathrm{C}$ and $\mathrm{pH} 6.0$, and required the presence of $\mathrm{Zn}^{2+}$. Size exclusion chromatographies and SDS-PAGE analysis led to the conclusion that this prolidase was a homodimer. Antibodies raised against the purified protein allowed the detection of PepQ among several Lactobacillus species but not lactococci. The pepQ gene and the upstream region were isolated and sequenced. The deduced peptide sequence showed that PepQ belongs to the M24 family of metallopeptidases. The pepR1 gene is located immediately upstream of pepQ and its product is homologous to the transcription factor CcpA, which is involved in catabolite repression of catabolic operons from Gram-positive bacteria. The pepR1-pepQ intergenic region contains a consensus catabolite-responsive element (CRE) which could be a target for PepR1 protein. Moreover, in contrast to other proline-specific enzymes from $L b$. bulgaricus, PepQ biosynthesis was shown to be dependent on the composition of the culture medium, but not on the peptide concentration. A possible regulation mechanism is discussed.
\end{abstract}

Keywords: prolidase, $p e p Q$ gene, Lactobacillus delbrueckii subsp. bulgaricus, CcpA

\section{INTRODUCTION}

Due to the unique structure of proline, the presence of this imino acid in a polypeptide chain restricts its susceptibility to proteolysis, so many proteases are unable to cleave a peptide bond involving proline. Caseins are proline-rich proteins which are hydrolysed during milk fermentation and cheesemaking conducted with lactic acid bacteria.

We have identified and characterized several proteolytic enzymes in Lactobacillus delbrueckii subsp. bulgaricus

Abbreviation: CRE, catabolite-responsive element.

The EMBL accession number for the sequence reported in this paper is Y13385.
CNRZ 397 (Lb. bulgaricus), a thermophilic lactic acid bacterium. The proline-rich oligopeptides resulting from casein hydrolysis by $\operatorname{PrtB}$, a cell-surface endoprotease (Gilbert et al., 1996), which are often bitter, are degraded by a set of proline-specific peptidases. The caseinolytic pathway leads to the liberation of free proline, which is essential to Lb. bulgaricus (Atlan et al., 1989), characterized by a high level of several prolinespecific activities. Prolyl aminopeptidase (EC 3.4.11.5, PepIP) is highly specific for di- or tripeptides with proline at the N-terminal position (Gilbert et al., 1994). The pepIP gene encoding this serine peptidase has been expressed at a very high level in Escherichia coli (Atlan et al., 1994). Another pathway of degradation of prolinecontaining peptides in Lb. bulgaricus involves an Xprolyl dipeptidyl aminopeptidase (EC 3.4.14.5, PepX) 
which is able to catalyse the removal of X-Pro dipeptides from oligopeptides containing a proline residue at the penultimate position. This serine peptidase is a homodimer of $150 \mathrm{kDa}$ (Atlan et al., 1990). X-Pro dipeptides can then be hydrolysed by a proline dipeptidase (EC 3.4.13.9, prolidase, PepQ) that has already been purified from Lactobacillus casei subsp. casei and Lactococcus lactis subsp. cremoris (Fernandez-Espla et al., 1997; Kaminogawa et al., 1984; Booth et al., 1990). The pepQ gene has recently been isolated from Lactobacillus delbrueckii subsp. lactis (Lb. lactis) and $L b$. bulgaricus B14 (Stucky et al., 1995; Rantanen \& Palva, 1997). Little is known about the effectors controlling the biosynthesis of proline-specific enzymes (Meyer et al., 1996).

In this paper, a broad investigation of PepQ from $L b$. bulgaricus CNRZ 397 was undertaken. PepQ activity was determined after growth of $L b$. bulgaricus cells in different media and the enzyme was purified and characterized. The $p e p Q$ gene was isolated and expressed in a PepQ-deficient strain of $E$. coli. In addition a survey of the occurrence of PepQ protein among lactic acid bacteria was performed.

\section{METHODS}

Bacterial strains and culture conditions. Bacterial strains used in this study are listed in Table 1. E. coli FM9001 is a RecA derivative from CM91 (Miller \& Schwartz, 1978) and was obtained by recombination with strain MCL31 (Lorence \& Rupert, 1983). Spontaneous mutants of FM9001 were selected on synthetic medium M63 (Miller, 1972) supplemented with glucose $\left(2 \mathrm{~g} \mathrm{l}^{-1}\right)$, amino acids (methionine, leucine and proline; $0.1 \mathrm{~g} \mathrm{l}^{-1}$ ) and $2 \mathrm{mM} \mathrm{Val-Pro-Leu.} \mathrm{Valine} \mathrm{is} \mathrm{toxic} \mathrm{for} \mathrm{E.} \mathrm{coli,}$ and only cells unable to hydrolyse the tripeptide were able to grow on this selective medium. The resulting mutant strain FM9003 selected for further study is deficient for prolidase (PepQ) and aminopeptidase $\mathrm{P}$ (PepP) activities. E. coli was grown aerobically at $37^{\circ} \mathrm{C}$ in LB medium (Miller, 1972). When required, LB medium was supplemented with $100 \mu \mathrm{g}$ ampicillin $\mathrm{ml}^{-1}, 100 \mu \mathrm{g}$ erythromycin $\mathrm{ml}^{-1}$ or $50 \mu \mathrm{g}$ kanamycin $\mathrm{ml}^{-1}$. Lactobacilli were routinely grown anaerobically in MRS broth (Difco) (de Man et al., 1960) at $40^{\circ} \mathrm{C}$ for thermophilic strains (Lb. bulgaricus, Lb. lactis and Lactobacillus helveticus) and $30^{\circ} \mathrm{C}$ for $\mathrm{Lb}$. casei. Lc. lactis was grown at $30^{\circ} \mathrm{C}$ in $\mathrm{M} 17$ broth supplemented with 5 g glucose $1^{-1}$ (Terzaghi \& Sandine, $1975)$. Reconstituted Gamma milk (10\%) was made by adding sterile water to skim milk powder sterilized by $\gamma$ radiations (Prolait, Niort, France). Growth was estimated by measuring $\mathrm{OD}_{600}$. One $\mathrm{OD}_{600}$ unit corresponds to $0.5 \mathrm{mg}$ and $0.25 \mathrm{mg}$ bacterial dry weight $\mathrm{ml}^{-1}$ for $E$. coli and $L b$. bulgaricus, respectively.

Preparation of cell extracts. For enzyme purification experiments, Lb. bulgaricus cells were collected at the end of the exponential growth phase, washed in $50 \mathrm{mM}$ sodium phosphate buffer $\mathrm{pH} 7 \cdot 2$ and resuspended in distilled water $\left(4 \times 10^{9}\right.$ cells $\mathrm{ml}^{-1}$ ). For other total cell extracts, lactic acid bacteria were grown in $50 \mathrm{ml}$ medium to exponential phase, washed and resuspended in $5 \mathrm{ml} 0 \cdot 2 \mathrm{M}$ Tris buffer $\mathrm{pH} 7 \cdot 0$. E. coli cells were grown in $50 \mathrm{ml} \mathrm{LB}$ medium supplemented with kanamycin, washed and resuspended in $5 \mathrm{ml} 0 \cdot 1 \mathrm{M}$ sodium citrate buffer pH 6.0. Cells were disrupted in a French pressure cell $(138 \mathrm{MPa})$. The homogenate was centrifuged at $15000 \mathrm{~g}$ for
$45 \mathrm{~min}$ or at $25000 \mathrm{~g}$ for $20 \mathrm{~min}$. The resulting supernatant (total cell extract) was used for further enzyme studies.

Protein and enzyme assays. Proteins were estimated by the method of Bradford (1976) with crystalline bovine serum albumin (Sigma) as a standard. PepQ activity was routinely assayed by the method of Yaron \& Mlynar (1968). Unless otherwise stated, the enzyme reaction was performed at $40^{\circ} \mathrm{C}$ in $0.25 \mathrm{ml} 0.1 \mathrm{M}$ sodium citrate buffer $\mathrm{pH} 6.0$, containing $2.5 \mathrm{mM} \mathrm{ZnSO}_{4}$ and $6.4 \mathrm{mM}$ Leu-Pro. The reaction was stopped by the addition of $0.62 \mathrm{ml}$ ninhydrin reagent $16 \mathrm{~g}$ ninhydrin dissolved in $200 \mathrm{ml}$ of a $6 \mathrm{M}$ phosphoric acid/glacial acetic acid mixture, $80: 120, \mathrm{v} / \mathrm{v}$ ) and $0.62 \mathrm{ml}$ glacial acetic acid. The solution was heated at $100^{\circ} \mathrm{C}$ for $30 \mathrm{~min}$ and the $A_{480}$ measured.

PepP activity was estimated by the assay of tyrosine released from human casomorphin. The reaction was carried out at $40^{\circ} \mathrm{C}$ in $0.1 \mathrm{M}$ sodium citrate buffer $\mathrm{pH} 6.0$ containing $5 \mathrm{mM}$ $\mathrm{ZnSO}_{4}$ and $0.5 \mathrm{mM}$ human casomorphin, and was stopped by rapid cooling. Products were analysed at room temperature by reverse-phase chromatography on a Pep RPC column (Pharmacia) equilibrated in $0.1 \%$ trifluoroacetic acid (TFA) in water (mobile phase A). The samples to be analysed were made up to $0.2 \mathrm{ml}$ with $A$ and injected onto the column, which was eluted as follows: from 0 to $3 \mathrm{~min}$, an isocratic elution with $\mathrm{A}$, and from 3 to $20 \mathrm{~min}$, a linear gradient of $100 \% \mathrm{~A}$ to $100 \% \mathrm{~B}$ (mobile phase B : $0 \cdot 1 \%$ TFA in acetonitrile). The flow rate was $0.7 \mathrm{ml} \mathrm{min} \mathrm{m}^{-1}$ and the UV detector was adjusted at 278 and $215 \mathrm{~nm}$. Under these conditions, tyrosine is eluted at $7.4 \mathrm{~min}$ and tyrosine-depleted human casomorphin and casomorphin at 14 and $15.25 \mathrm{~min}$, respectively. Amino acids were separated by thin-layer chromatography on silica gel $60 \mathrm{~F} 254$ thin-layer plates (Merck). Acetic acid/n-butanol/water $(1 / 4 / 1$, by vol.) was used as the developing solvent, and $0.25 \%(\mathrm{w} / \mathrm{v})$ ninhydrin in acetone as the locating agent. The spots were developed by heating at $100^{\circ} \mathrm{C}$ for $5 \mathrm{~min}$.

PepX, PepIP and PepN activities were assayed as described previously with respectively Ala-Pro-, Pro- and Lys- $p$ nitroanilide as the substrate (Gilbert et al., 1997). One unit of enzyme activity was defined as the amount of enzyme that releases $1 \mu \mathrm{mol}$ product (proline, tyrosine or $p$-nitroanilide) $\min ^{-1}$.

PepQ enzyme purification. A total extract $(197 \mathrm{ml})$ from $L b$. bulgaricus was treated with $\left(\mathrm{NH}_{4}\right)_{2} \mathrm{SO}_{4}$ at $60 \%$ saturation. The $60 \%$ supernatant was brought to $100 \%$ saturation. Fractions obtained at $60 \%$ and $100 \%\left(\mathrm{NH}_{4}\right)_{2} \mathrm{SO}_{4}$ were pooled and applied to a column $(12 \times 2.6 \mathrm{~cm})$ of DEAE-Trisacryl

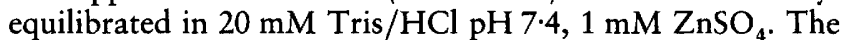
column was then washed with $50 \mathrm{ml}$ of the equilibration buffer. Elution was performed using a linear gradient from 0 to $500 \mathrm{mM} \mathrm{NaCl}$ (total volume $300 \mathrm{ml}$ ) at a flow rate of $1.5 \mathrm{ml}$ $\mathrm{min}^{-1}$. Fractions of $6 \mathrm{ml}$ were collected and two peaks of UVabsorbing material, named $\mathrm{A}$ and $\mathrm{B}$, were eluted at $250 \mathrm{mM}$ and $400 \mathrm{mM} \mathrm{NaCl}$ concentrations, respectively. Peak A contained the enzyme activity; it was then chromatographed on a Source $15 \mathrm{Q}$ column $(7.5 \times 0.75 \mathrm{~cm})$ equilibrated in $20 \mathrm{mM}$ sodium acetate $\mathrm{pH} \mathrm{5.5,1 \textrm {mM } \mathrm { ZnSO }}$. Chromatography was developed at a flow rate of $0.75 \mathrm{ml} \mathrm{min}$ as follows: from 0 to $5 \mathrm{~min}$, the equilibration buffer, then for $60 \mathrm{~min}$, a linear gradient from 0 to $300 \mathrm{mM} \mathrm{NaCl} ; 1.5 \mathrm{ml}$ fractions were collected and the active fraction was loaded onto a Mono $Q$ HR 5/5 column (Pharmacia) equilibrated in $20 \mathrm{mM}$ sodium acetate $\mathrm{pH} 4 \cdot 8,1 \mathrm{mM} \mathrm{ZnSO}_{4}$. Chromatography was developed at room temperature as follows: from 0 to $3 \mathrm{~min}$, the equilibration buffer, then for $30 \mathrm{~min}$, a linear gradient from 0 to $300 \mathrm{mM} \mathrm{NaCl}$; the flow rate was set at $1 \mathrm{ml} \mathrm{min}^{-1}$ and $1 \mathrm{ml}$ 
Table 1. Bacterial strains and plasmids

\begin{tabular}{|c|c|c|}
\hline Strain or plasmid & Genotype or relevant characteristics & Source or reference \\
\hline \multicolumn{3}{|l|}{ Strains } \\
\hline \multicolumn{2}{|l|}{$\begin{array}{l}\text { Lactobacillus delbrueckii subsp. } \\
\text { bulgaricus CNRZ } 397\end{array}$} & INRA, Jouy en Josas, France \\
\hline \multicolumn{2}{|l|}{$\begin{array}{l}\text { Lactobacillus delbrueckii subsp. } \\
\text { lactis CNRZ } 250\end{array}$} & INRA, Jouy en Josas, France \\
\hline \multicolumn{2}{|l|}{ Lactobacillus helveticus NCDO 766} & $\begin{array}{l}\text { Institute of Food Research, } \\
\text { Reading, UK }\end{array}$ \\
\hline \multicolumn{2}{|l|}{ Lactobacillus casei ATCC 4646} & $\begin{array}{l}\text { TNO Nutrition \& Food Institute, } \\
\text { Rijswik, The Netherlands }\end{array}$ \\
\hline \multicolumn{2}{|l|}{$\begin{array}{l}\text { Lactococcus lactis subsp. lactis } \\
\text { NCDO } 763\end{array}$} & Yakult Central Institute for \\
\hline \multicolumn{2}{|l|}{ NCDO 763} & $\begin{array}{l}\text { Microbial Research Kunitachi- } \\
\text { shi, Tokyo, Japan }\end{array}$ \\
\hline Escherichia coli CM91 & leu-9 $\Delta$ (pro-lac) met thyA pepQ12 & Miller \& Schwartz (1978) \\
\hline Escherichia coli MCL31 & Hfr PO201, $\Delta(s r l-r e c A) 306:: \operatorname{Tn} 10$ & Lorence \& Rupert (1983) \\
\hline Escherichia coli FM9001 & $\mathrm{RecA}^{-}$derivative from $\mathrm{CM} 91$ & This work \\
\hline Escherichia coli FM9003 & Val-Pro-Leu-resistant $\left(\mathrm{PepP}^{-}\right)$derivative of FM9001 & This work \\
\hline \multicolumn{3}{|l|}{ Plasmids } \\
\hline pUC18 & $2.7 \mathrm{~kb}, \mathrm{Amp}^{\mathrm{r}}, \mathrm{lacZ} \alpha$ & Yanisch-Perron et al. (1985) \\
\hline pJDC9 & $7.0 \mathrm{~kb}, \mathrm{Ery}^{\mathrm{r}}, \mathrm{lacZ} \alpha$ & Chen \& Morrison (1987) \\
\hline pLG339 & $6 \cdot 2 \mathrm{~kb}, \operatorname{Tet}^{\mathrm{r}} \mathrm{Kan}^{\mathrm{r}}$ & Stoker et al. (1982) \\
\hline pQF6 & $\begin{array}{l}\text { pUC18 derivative containing the PCR fragment } \\
(1.2 \mathrm{~kb}) \text { corresponding to } p e p Q \text { of } L b . \text { bulgaricus }\end{array}$ & This work \\
\hline pQA3 & $\begin{array}{l}\text { pUC18 derivative containing the inverse PCR fragment } \\
(1.5 \mathrm{~kb}) \text { corresponding to } p e p Q \text { promoter region of } \\
\text { Lb. bulgaricus }\end{array}$ & This work \\
\hline pRF1 & $\begin{array}{l}\text { pJDC9 derivative containing the inverse PCR fragment } \\
(2 \cdot 2 \mathrm{~kb}) \text { corresponding to } p e p R 1 \text { of } \\
\text { Lb. bulgaricus }\end{array}$ & This work \\
\hline pMS2 & pLG339 derivative containing $p e p Q$ of $L b$. lactis & Stucky et al. (1995) \\
\hline pQLB18 & $\begin{array}{l}\text { pMS2 derivative containing } p e p Q \text { of } L b . \text { bulgaricus } \\
\text { with promoter of } L b \text {. lactis }\end{array}$ & This work \\
\hline pQBB12 & $\begin{array}{l}\text { pQLB18 derivative containing } p e p Q \text { of } L b . \text { bulgaricus } \\
\text { with its own promoter }\end{array}$ & This work \\
\hline
\end{tabular}

fractions were collected. The active fraction was treated by hydrophobic interaction chromatography at $20^{\circ} \mathrm{C}$, using a $1 \mathrm{ml}$ phenyl Sepharose HP column (Pharmacia). The column was equilibrated in $20 \mathrm{mM}$ sodium acetate $\mathrm{pH} 5.5,1 \mathrm{mM}$ $\mathrm{ZnSO}_{4}, 1 \mathrm{M}\left(\mathrm{NH}_{4}\right)_{2} \mathrm{SO}_{4}$, and eluted as follows: from 0 to 4 min, the equilibration buffer, and from 4 to $30 \mathrm{~min}$, a descending linear gradient from $1 \mathrm{M}$ to $0 \mathrm{M}\left(\mathrm{NH}_{4}\right)_{2} \mathrm{SO}_{4}$. Fractions of $0.8 \mathrm{ml}$ were collected with a flow rate of $0.4 \mathrm{ml}$ $\mathrm{min}^{-1}$. Finally, the active fraction was treated by size-exclusion chromatography at room temperature on a Superose $12 \mathrm{HR}$ column (Pharmacia) equilibrated in $20 \mathrm{mM}$ sodium acetate pH 5.5, $1 \mathrm{mM} \mathrm{ZnSO}, 100 \mathrm{mM} \mathrm{NaCl}$. The flow rate was $0.4 \mathrm{ml} \mathrm{min}^{-1}$ and $0.8 \mathrm{ml}$ fractions were collected. Cytochrome c $(12.4 \mathrm{kDa})$, carbonic anhydrase $(29 \mathrm{kDa})$, ovalbumin $(46 \mathrm{kDa})$, bovine serum albumin $(69 \mathrm{kDa})$ and $\alpha$-amylase $(200 \mathrm{kDa})$ were the molecular mass standards.

Electrophoretic techniques, Western blotting and immunoblotting. SDS-PAGE was carried out by the method of Laemmli (1970). Proteins were visualized using the Quick Silver detection kit (Amersham) or by Coomassie blue.

Thin-layer gel electrofocusing was performed with the LKB2117-Multiphor II (LKB Produkter) in the $\mathrm{pH} \mathrm{3.5-10}$ range; the gel was $0.5 \mathrm{~mm}$ thick. The detection procedure was the same as for SDS-PAGE.

Western blotting was performed by electrotransfer with the LKB2117-Multiphor II onto nitrocellulose membrane (Schleicher \& Schuell). Immunoblots were carried out by the method of Harlow \& Lane (1988) using antibodies raised against the purified $L b$. bulgaricus PepQ protein and antirabbit IgG peroxidase conjugate (Sigma). Anti-PepQ polyclonal antibodies were provided by the Centre de Bioexpérimentation Valbex (IUT A, Université Lyon I).

$\mathrm{N}$-terminal sequence determination. The $\mathrm{N}$-terminal sequence of PepQ was determined by the method described by Edman \& Begg (1967) at the Service Central d'Analyse CNRS (Vernaison, France).

Recombinant DNA procedures. Restriction endonucleases, Klenow DNA polymerase, T4 DNA ligase and T4 polynucleotide kinase were obtained from New England Biolabs and Life Technologies-Gibco-BRL, and used according to the manufacturers' instructions. Plasmid extraction and E. coli transformation were carried out as described by Sambrook et al. (1989). DNA fragments were purified with the UltraClean 
Gen-apex DNA purification kit (Prolabo). DNA sequencing was performed using the T7-sequencing kit (Pharmacia).

PCR and inverse PCR amplifications, and plasmid construction. Plasmids used in this study are listed in Table 1. PCR was performed using the Advantage ${ }^{\text {TM }}$ Genomic PCR kit (Clontech) and primers were provided by Life TechnologiesGibco-BRL. The kit contains a polymerase providing $3^{\prime}-5^{\prime}$ proof-reading activity, which ensures high fidelity. PCR amplification of the $p e p Q$ gene was carried out with chromosomal DNA from $L b$. bulgaricus CNRZ 397 as a matrix and primers QStart $\left(5^{\prime}\right.$ CCCATCGATTTAGACAAATTACAAAAC $3^{\prime}$ ) and QStop (5' GCGCAAGGCATAATTGTATACGA $3^{\prime}$ ) (see Fig. 2a). These primers were chosen according to the sequence of pepQ from Lb. lactis DSM 7290 (Stucky et al., 1995). Primer QStart contains the ATG start-codon and two base changes allowed the insertion of a ClaI restriction site. Primer QStop is located $76 \mathrm{nt}$ downstream the stop-codon of the pepQ gene and contains a Bst11071 restriction site. PCR product was digested with ClaI and Bst1107I restriction enzymes and inserted into the pUC18 vector (pQF6; see Table 1 and Fig. 2a). Inverse PCR, performed by the method of Ochman et al. (1990), was used to amplify the chromosomal region upstream of $p e p Q$. For amplification of the promoter region, chromosomal DNA from $L b$. bulgaricus was digested with EcoRI. Resulting fragments were circularized with T4 DNA ligase, and used for PCR amplification with primers InvQ1 ( $5^{\prime}$ GTCCATCCCGTTTTCCTGC $\left.3^{\prime}\right)$ and InvQ2 $\left(5^{\prime}\right.$ GAAGAAGCCAAGGCATCAGC 3') (see Fig. 2a). These primers have divergent directions and are located in the $5^{\prime}$ part of the pepQ gene. They were chosen according to the sequence of pepQ from $L b$. bulgaricus CNRZ 397. The PCR product was cloned into the pUC18 vector after Klenow and kinase treatments (pQA3, Table 1). For the amplification of pepR1, chromosomal DNA from $L b$. bulgaricus was digested with PstI. Resulting fragments were circularized and used for PCR amplification with primers InvR1 (5' CCGTTTGATGAAGGAAGACGCCG $\left.3^{\prime}\right)$ and InvR2 (5' ACATTGTTGTTGCCGTTGACTACCCG 3') (see Fig. 2a). These primers have divergent directions and are located in the $5^{\prime}$ part of the pepR1 gene. They were chosen according to the sequence of pepR1 from Lb. bulgaricus CNRZ 397. The PCR product was cloned into the pJDC9 vector after Klenow and kinase treatments (pRF1, Table 1). Plasmid pQLB18 was constructed by replacing the $1.1 \mathrm{~kb} P s t \mathrm{I}-X b a \mathrm{I}$ fragment of $\mathrm{pMS} 2$ with the $1.1 \mathrm{~kb}$ PstI-XbaI fragment of pQF6, corresponding to the pepQ-encoding region of Lb. bulgaricus (Table 1 and Fig. 2a). Plasmid pQBB12 was derived from pQLB18, in which the $0.6 \mathrm{~kb}$ EcoRI-PstI fragment was replaced by the $0.6 \mathrm{~kb}$ EcoRI-Pst I fragment of pQA3, corresponding to the promoter region of $L b$. bulgaricus (Table 1 and Fig. 2a).

\section{RESULTS}

\section{Peptidase activities of $\mathbf{L b}$. bulgaricus}

Activities of three proline-specific peptidases (PepQ, PepX, PepIP) and a general aminopeptidase (PepN) were assayed in total cell extracts from Lb. bulgaricus. Bacterial cells were grown in MRS, a peptide-rich medium, or in milk, which contains a very low amount of peptides and free amino acids (Table 2). PepX, PepIP and PepN activities did not significantly differ after bacterial growth in MRS or milk. By contrast, PepQ activity assayed from MRS cultures was twofold higher than that from milk cultures $\left(2.6\right.$ and $1.3 \mathrm{U} \mathrm{mg}^{-1}$, respectively). The addition of peptides (tryptone or Leu-
Table 2. Peptidase activities of $L b$. bulgaricus CNRZ 397 after growth in different media

Activities are in units ( $\mathrm{mg}$ bacterial dry weight) ${ }^{-1}$ and are the mean values from at least three independent assays.

\begin{tabular}{|lcccc|}
\hline Medium & PepQ & PepX & PepIP & PepN \\
\hline MRS & $2 \cdot 6$ & 177 & $16 \cdot 8$ & $26 \cdot 0$ \\
Milk & $1 \cdot 3$ & 140 & $17 \cdot 6$ & $26 \cdot 8$ \\
Milk + tryptone 1\% & $1 \cdot 1$ & 137 & $21 \cdot 4$ & $24 \cdot 7$ \\
Milk + Leu-Pro 5 mM & $1 \cdot 0$ & 120 & $17 \cdot 3$ & $21 \cdot 6$ \\
\hline
\end{tabular}

Pro) to milk cultures did not significantly modify PepQ activity.

\section{PepQ purification and properties}

PepQ purification was achieved by a six-step procedure described in Methods; quantitative results are summarized in Table 3 . The purified protein was electrophoretically pure (Fig. 1) and was used for all the enzyme characterizations. In order to keep the prolidase activity at a reasonable level, it was necessary to carry out all the purification steps in the presence of $1 \mathrm{mM}$ $\mathrm{ZnSO}_{4}$.

Under our assay conditions, PepQ activity was optimal in the range $40-50^{\circ} \mathrm{C}$ and fell abruptly beyond $50^{\circ} \mathrm{C}$ and $55^{\circ} \mathrm{C}$. The optimal $\mathrm{pH}$ was 6.0 . The isoelectric point of PepQ was $\mathrm{pH} 4 \cdot 5$. At $40^{\circ} \mathrm{C}$, the substrate LeuPro was hydrolysed with a $K_{\mathrm{m}}$ of $2 \cdot 2 \mathrm{mM}$ and a $V_{\max }$ of $0.33 \mathrm{mmol} \mathrm{min}^{-1}$ (mg protein) ${ }^{-1}$.

PepQ is not a serine enzyme since it was inhibited neither by $1 \mathrm{mM} \quad p$-amidinophenylmethylsulfonylfluoride (APMSF) nor by $1 \mathrm{mM}$ 3,4-dichloroisocoumarin. Complete inhibition occurred in the presence of $1 \mathrm{mM}$ bestatin or $1 \mathrm{mM}$ DTT. PepQ activity was inhibited by $1 \mathrm{mM}$ EDTA, and in order to reverse this inhibition or to activate the prolidase, $\mathrm{Zn}^{2+}$ was found to be the best of the divalent cations tested $\left(\mathrm{Zn}^{2+}, \mathrm{Ca}^{2+}\right.$, $\left.\mathrm{Co}^{2+}, \mathrm{Cu}^{2+}, \mathrm{Mg}^{2+}, \mathrm{Mn}^{2+}, \mathrm{Ni}^{2+}\right)$.

Studies of substrate specificity showed that the purified enzyme is highly specific for dipeptides of the X-Pro type, except for Pro-Pro and Gly-Pro, which underwent very low hydrolysis (if any) as compared with the dipeptides made of Arg, Leu, Phe, Val as N-terminal amino acid (Table 4). Therefore, the purified enzyme is strictly a proline dipeptidase with no detectable PepP activity.

On SDS-PAGE, the enzyme migrated like a molecule of about $50 \mathrm{kDa}$ (Fig. 1). On size-exclusion chromatography and under non-denaturing conditions $[20 \mathrm{mM}$ sodium acetate, $1 \mathrm{mM} \mathrm{ZnSO}_{4}, 100 \mathrm{mM}$ (or $300 \mathrm{mM}$ ) $\mathrm{NaCl}$ pH 5.5 buffer], the apparent molecular mass ranged from 68 to $70 \mathrm{kDa}$; under denaturing conditions (5 M urea), the apparent molecular mass dropped to approximately $45 \mathrm{kDa}$, a value very close to that determined from the deduced amino acid sequence 
Table 3. Distribution of protein and prolidase activity upon purification of the total extract

\begin{tabular}{|c|c|c|c|c|c|}
\hline Purification step & Protein (mg) & $\begin{array}{c}\text { Enzyme activity } \\
\quad\left(\mu \mathrm{mol} \mathrm{min}^{-1}\right)\end{array}$ & $\begin{array}{c}\text { Specific activity } \\
\left(\mu \mathrm{mol} \mathrm{min}^{-1} \mathrm{mg}^{-1}\right)\end{array}$ & Recovery* & $\begin{array}{l}\text { Purification } \\
\text { factor }\end{array}$ \\
\hline Total extract & 354 & 2730 & $7 \cdot 7$ & 100 & 1 \\
\hline$\left(\mathrm{NH}_{4}\right)_{2} \mathrm{SO}_{4}, 60 \%$ sat. & 99 & 284 & $2 \cdot 86$ & 10 & $0 \cdot 37$ \\
\hline$\left(\mathrm{NH}_{4}\right)_{2} \mathrm{SO}_{4}, 100 \%$ sat. & 202 & 2280 & $11 \cdot 2$ & 83 & $1 \cdot 45$ \\
\hline DEAE-Trisacryl & 71 & 1900 & 26 & 69 & $3 \cdot 37$ \\
\hline Source $15 \mathrm{Q}$ & 13 & 1340 & 103 & 49 & $13 \cdot 3$ \\
\hline Mono Q & $2 \cdot 8$ & 710 & 253 & 26 & 33 \\
\hline Hydrophobic interaction chromatography & $1 \cdot 3$ & 412 & 316 & 15 & 41 \\
\hline Size-exclusion chromatography & $0 \cdot 38$ & 170 & 446 & $6 \cdot 2$ & 58 \\
\hline
\end{tabular}

* Recovery is the enzyme activity in the fraction expressed as a percentage of that in the total extract.

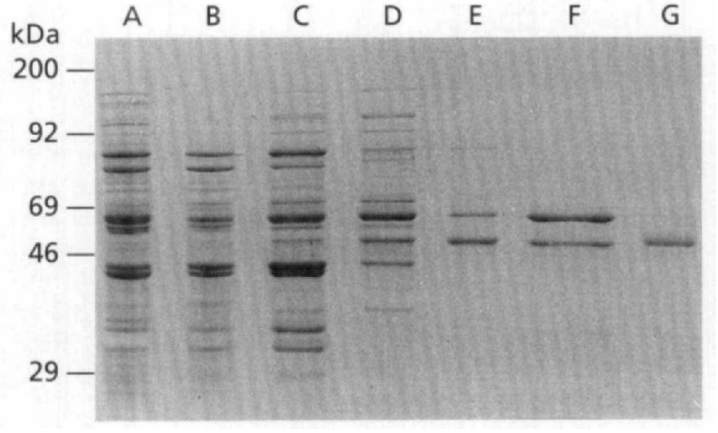

Fig. 1. SDS-PAGE analysis of the fractions obtained in the course of the PepQ purification. Lane A, total extract; lane $B$, $\left(\mathrm{NH}_{4}\right)_{2} \mathrm{SO}_{4}$ precipitate; lane $\mathrm{C}$, DEAE-Trisacryl chromatography; lane D, chromatography on Source 15Q; lane $E$, chromatography on Mono Q; lane $F$, hydrophobic interaction chromatography; lane G, size-exclusion chromatography. Myosin (200 kDa), phosphorylase b $(92 \mathrm{kDa})$, bovine serum albumin $(69 \mathrm{kDa})$, ovalbumin $(46 \mathrm{kDa})$ and carbonic anhydrase $(29 \mathrm{kDa})$ were the molecular mass standards.

encoded by $p e p Q(41 \mathrm{kDa})$. Taken together, the results strongly suggest that PepQ is a homodimer.

\section{Cloning and analysis of the pepQ gene region}

QStart and QStop primers were used for the PCR amplification of pep $Q$ from the $L b$. bulgaricus chromosome. Considering the high DNA sequence identity between $L b$. delbrueckii subspecies, these primers were chosen according to the sequence of the $p e p Q$ gene from Lb. lactis DSM 7290 (Stucky et al., 1995). A single $1.2 \mathrm{~kb}$ PCR product was obtained and cloned into the pUC18 vector ( $\mathrm{pQF} 6$, Table 1). Inverse PCR was used to amplify the chromosomal region upstream of the $p e p Q$ gene, with primers chosen according to the $L b$. bulgaricus CNRZ 397 sequence. A single inverse-PCR product of $1.5 \mathrm{~kb}$ was obtained with InvQ1 and InvQ2 primers, and cloned into the pUC18 vector (pQA3, Table 1). A second $2 \cdot 2 \mathrm{~kb}$ inverse PCR product was obtained with InvR1
Table 4. Substrate specificity of purified PepQ

\begin{tabular}{|lc|}
\hline Substrate & Activity \\
\hline Leu-Pro* & 100 \\
Arg-Pro* & 130 \\
Pro-Pro* & 0 \\
Val-Pro* & 82 \\
Ala-Pro* & 15 \\
Gly-Pro* & 0 \\
Phe-Pro* & 75 \\
Leu-Gly $\dagger$ & - \\
Leu-Ala $\dagger$ & - \\
Leu-Ala-Pro* & 0 \\
Gly-Pro-Ala $\dagger$ & - \\
Ala-Pro-Gly & - \\
Val-Pro-Leu & - \\
Human casomorphin $\neq$ & 0 \\
\hline
\end{tabular}

*Prolidase activity was measured by assaying the release of proline (Yaron \& Mlynar, 1968); relative activity is a percentage of the activity obtained with Leu-Pro (446 $\mathrm{U} \mathrm{mg}^{-1}$ ).

†Thin-layer chromatography on silica gel 60F254 was used to look for a release of the N-terminal amino acid. -, No release of amino acid observed.

¥The susceptibility of human casomorphin to the prolidase action was studied by measuring the appearance of tyrosine by reverse phase chromatography.

and InvR2 primers, and cloned into the pJDC9 vector (pRF1, Table 1).

The sequence of the overall region (3553 nt) was determined from DNA inserts of pQF6, pQA3 and pRF1. Nucleotide sequence comparison with the corresponding region from $L b$. lactis DSM 7290 showed $98 \%$ identity (Stucky et al., 1995, 1996). DNA sequence analysis revealed two divergent open reading frames (ORFs) (Fig. 2a). One ORF encodes 368 amino acid residues and corresponds to $p e p Q$. Immediately upstream, a second ORF ( 333 codons) was named pepR1 
(a)

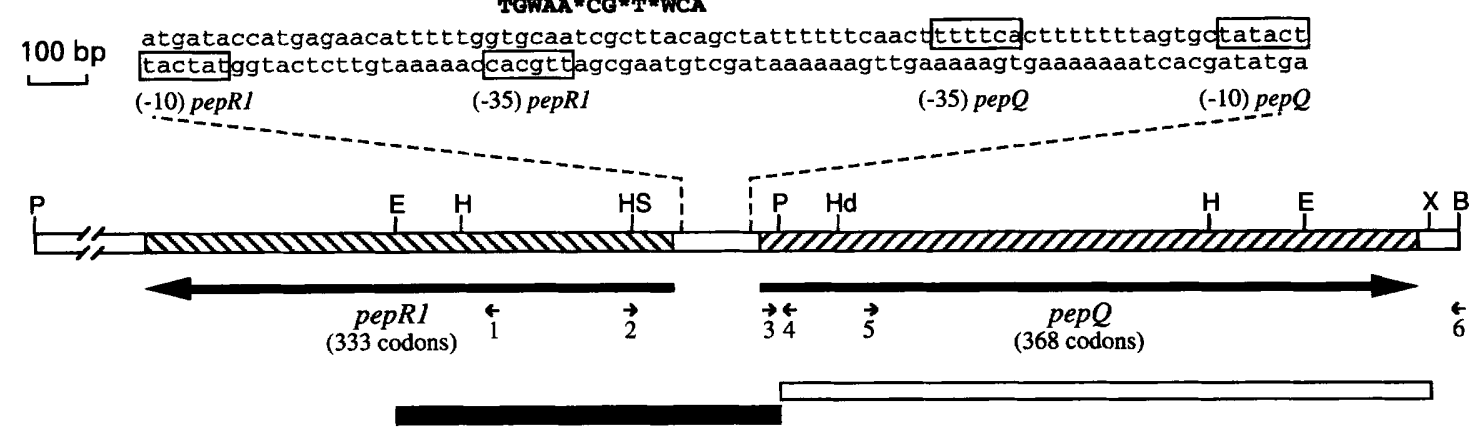

(b)
Consensus RBS sequence of $L b$. delbrueckii
RBS sequence of pepRl from $L b$. bulgaricus
AGGAGGA
RBS sequence of pepRl from $L b$. lactis
AGGTGGG
3 '-end sequence of 16S rRNA from $E$. coli
AGGTAGG
3'OH-AUUCCUCCA

\begin{abstract}
Fig. 2. Genetic map of the chromosomal region of $p e p Q$ and comparison of putative RBS sequences of pepR1. (a) Genetic map. Restriction sites: E, EcoRl; H, Hincll; S, Smal; P, Pstl; Hd, HindlII; X, Xbal; B, Bst1107I. The pepQ and pepR1 genes are indicated by striped zones and arrows. Details of intergenic region: putative -10 and -35 sequences of both genes are boxed, and the CRE sequence is presented with the consensus CRE sequence above. Position and direction of primers used for direct and inverse PCR are indicated by small arrows: 1, InvR1; 2, InvR2; 3, QStart; 4, InvQ1; 5, InvQ2; 6, QStop. The $1.1 \mathrm{~kb}$ Pstl-Xbal fragment of pQF6 and the $0.6 \mathrm{~kb}$ EcoRI-Pstl fragment of pQA3 are represented by white and black bars, respectively. (b) Comparison of putative RBS sequences of pepR1: nucleotides according to the consensus RBS sequence are in bold letters (Matern et al., 1994); nucleotides of the 165 rRNA from $E$. coli that could hybridize to the RBS sequence of pepR1 from $L b$. delbrueckii are underlined (Shine \& Dalgarno, 1974).
\end{abstract}

in reference to $L b$. lactis DSM 7290. The pepQ-pepR1 intergenic region contains a putative -35 box,-10 box and RBS promoter sequences of both genes (Fig. 2a). The two -35 sequences are separated by $25 \mathrm{bp}$. The $L b$. bulgaricus RBS sequence of $p e p R 1$ differs in one base from that of Lb. lactis DSM 7290 (Fig. 2b). A wellconserved consensus catabolite-responsive element (CRE) overlaps the -35 box of pepR1.

\section{Amino acid sequence analysis of PepQ protein}

The deduced amino acid sequence of PepQ is in agreement with the first 20 amino acids of the $\mathrm{N}$ terminal sequence of the purified enzyme (data not shown). Comparison of PepQ sequences from $L b$. bulgaricus CNRZ 397 and B14 revealed only one different residue at position 93 (Thr instead of Ser) (Rantanen \& Palva, 1997); thus, the Lb. bulgaricus CNRZ 397 and Lb. lactis DSM 7290 PepQ sequences only differ in three residues (Stucky et al., 1995).

A computer search in protein databases revealed significant similarity between the amino acid sequence of $L b$. bulgaricus PepQ and aminopeptidases P (PepPs), methionyl aminopeptidases (PepMs) and creatinases, particularly in the C-terminal two-thirds of the sequences. According to Rawlings \& Barrett (1995), prolidases, PepPs and PepMs constitute the M24 family of metallopeptidases. Previous reports concerning PepQ from Lb. lactis DSM 7290 and Lb. bulgaricus B14 claimed that these enzymes contain a $\mathrm{Zn}$-binding site (HEXXH motif) characterizing Zn-metallopeptidases (Stucky et al., 1995; Rantanen \& Palva, 1997). In contrast to this statement, proteins of M24 family are characterized by the absence of a consensus $\mathrm{Zn}$-binding motif and contain metal atoms that are not necessarily zinc. The three-dimensional structure of PepM from $E$. coli shows that the active site consists of five residues binding two cobalt atoms (Roderick \& Matthews, 1993). These five metal ligands (Asp-223, Asp-234, His298, Glu-327 and Glu-341 in the PepQ sequence of $L b$. bulgaricus) are well conserved as shown in Fig. 3.

The deduced amino acid sequence of PepR1 exhibits $50 \%$ identity with CcpA of $L b$. casei ATTC 393 (Monedero et al., 1997). PepR1 was found to be related to the LacI-GalR repressor family and showed a helix-turn-helix motif characteristic of DNA-binding proteins. Restricted to this domain, sequence identity between PepR1 and Lb. casei ATCC 393 CcpA was $95 \%$.

\section{Expression of pepQ in E. coli FM9003}

Plasmids pMS2, pQLB18 and pQBB12 are pLG339 derivatives (Table 1). pMS2 and pQBB12 contain, respectively, $p e p Q$ genes from $L b$. lactis DSM 7290 and Lb. bulgaricus CNRZ 397 with their own promoters. In 


$\begin{array}{ccc} & \mathbf{2 2 3} & \mathbf{2 3 4} \\ 1 & \text { ELVLFDLGTMHEGYASDSSRTV } \\ 2 & \text { RSFLLDAGAEYNGYAADLTRTW } \\ 3 & \text { DMCLFDMGGEYYSVASDITCSF } \\ 4 & \text { DLVLIDAGCEYKGYAGDITRTF } \\ 5 & \text { DPVTIDFGCYYEHYASDMTRTI } \\ 6 & \text { DIVNIDVTVIKDGFHGDTSKMF } \\ 7 & \text { DIISIDIGAKLNGYHGDSAWTY } \\ & \star\end{array}$

298

GHGIGMEVHEF PSI

GHPLGLQVHDVAGF

GHFLGIDVHDVGGY

SHWLGLDVHDVGVY

GHGLGLDVHEI PYF

GHGIGRGFHEEPQV

GHGVGQDLHEDPQI
327

VLEEGMCFSIEPGIY ILQPGMVLTIEPGIY HLQPGMVLTVEPGIY ILEPGMVLTVEPGLY QLRSGMVITDEPGIY VLKPGMTFTIEPMVN RLKPGMVLAIEPMVN

\section{1}

FAGVRIEDCGVLTK FGGIRIEDNVVIHE FGGVRIEEDVVVID GIGIRIEDDIVITE FGGVRIEDDLLVTE SLSAQYEHTIVVTD KKCAHFEHTIAITE

Fig. 3. Multiple sequence alignment of M24 family peptidases: lines 1 and 2, PepQs from Lb. bulgaricus (Y13385) and $E$. coli (P21165) (Nakahigashi \& Inokuchi, 1990), respectively; line 3, human prolidase (PepD) (P12955) (Tanoue et al., 1990); lines 4 and 5, PepPs from E. coli (P15034) (Yoshimoto et al., 1989) and Lc. lactis (Y08842) (Matos et al., 1998), respectively; lines 6 and 7, PepMs from E. coli (P07906) (Fujita et al., 1994) and Bacillus subtilis (P19994) (Nakamura et al., 1990), respectively. Database accession numbers are listed above in parentheses after each species. The five conserved metal ligands are shown in bold letters; numbering corresponds to the sequence of $L b$. bulgaricus PepQ; conserved amino acids are indicated by an asterisk.

Table 5. Expression of pepQ from $L b$. bulgaricus in $E$. coli FM9003

Activities are in units ( $\mathrm{mg}$ bacterial dry weight) $)^{-1}$ and are the mean values from at least three independent assays.

\begin{tabular}{|lcc|}
\hline Plasmid & $\mathbf{1 0}^{\mathbf{3}} \times$ PepQ activity & PepN activity \\
\hline pLG339 & $<0 \cdot 1$ & $2 \cdot 1$ \\
pMS2 & $20 \cdot 8$ & $2 \cdot 2$ \\
pQLB18 & $23 \cdot 4$ & $1 \cdot 7$ \\
pQBB12 & $49 \cdot 9$ & $2 \cdot 1$ \\
\hline
\end{tabular}

pQLB18, the Lb. bulgaricus gene was cloned downstream of the pepQ promoter from Lb. lactis DSM 7290.

E. coli FM9003, which is unable to hydrolyse the LeuPro dipeptide, was transformed with pLG339, pMS2, pQLB18 and pQBB12. PepQ and PepN activities were assayed in total cell extracts obtained from transformants. PepN was used as an internal standard of $E$. coli. No PepQ activity was present in the extract from the strain harbouring pLG339 (Table 5). PepQ activities encoded by pMS2 and pQLB18 were not significantly different $\left(20.8 \times 10^{-3}\right.$ and $23.4 \times 10^{-3} \mathrm{U} \mathrm{mg}^{-1}$, respectively), indicating that the PepQ proteins from both $L b$. delbrueckii subspecies have similar enzyme properties. By contrast, the presence of pQBB12 was associated with a 2.5 -fold higher activity $\left(49.9 \times 10^{-3} \mathrm{U} \mathrm{mg}^{-1}\right)$. Taken together, these results suggested that the promoter region from $L b$. bulgaricus led to a better transcription level of pepQ than that from $L b$. lactis DSM 7290.

\section{Immunodetection of PepQ in lactic acid bacteria}

Western blot analysis of total cell extracts from E. coli transformants harbouring pLG339, pMS2, pQLB18 or pQBB12, and from $L b$. bulgaricus CNRZ 397, Lb. lactis CNRZ 250, Lb. helveticus NCDO 766, Lb. casei ATCC 4646 and Lc. lactis NCDO 763 was performed after SDS-PAGE, with antibodies raised against the purified

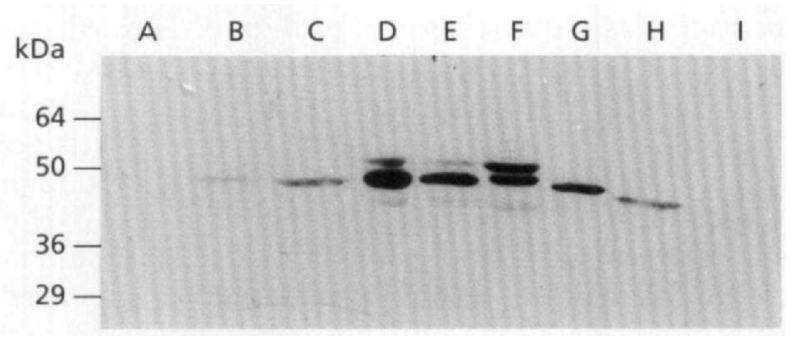

Fig. 4. PepQ immunodetection in total extracts from transformants of $E$. coli FM9003 and from lactic acid bacteria: proteins from total extracts were separated by SDS-PAGE. Lanes $A-C, E$. coli FM9003 harbouring pLG339, pMS2 or pQBB12, respectively (amounts of total extracts used correspond approximately to $2 \times 10^{8}$ cells); lanes $\mathrm{D}$ and $\mathrm{E}, \mathrm{Lb}$. bulgaricus CNRZ 397 after growth in MRS or milk, respectively; lanes F-H, Lb. lactis CNRZ 250, Lb. helveticus NCDO 766, Lb. casei ATCC 4646, respectively after growth in MRS; lane I, Lc. lactis NCDO 763 after growth in M17-glucose. To obtain readable blots, amounts of total extracts correspond to about $10 \mu \mathrm{g}$ proteins for lanes $D$ and $E, 20 \mu \mathrm{g}$ for lanes $F$ and $G$, and $80 \mu \mathrm{g}$ for lanes $\mathrm{H}$ and $\mathrm{I}$; SeeBlue prestained standard solution (Novex) was used for molecular mass markers.

PepQ from Lb. bulgaricus (Fig. 4). A single $48 \mathrm{kDa}$ band was observed in extracts from $E$. coli strains carrying pMS2, pQLB18 or pQBB12, whereas no signal was observed with strains harbouring pLG339. This apparent size was in accordance with the SDS-PAGE migration of the purified protein (Fig. 1).

A major protein (about $48 \mathrm{kDa}$ ) corresponding to the PepQ protein was detected in total extracts from $L b$. bulgaricus and $L b$. lactis CNRZ 250. A single protein was also detected in $L b$. belveticus NCDO 766 and $L b$. casei ATCC 4646 extracts, but with a different molecular mass ( 45 and $42 \mathrm{kDa}$, respectively). No protein signal was detected in the Lc. lactis NCDO 763 extract. Thus, PepQ protein appeared well conserved within lactobacilli.

A minor band (about $40 \mathrm{kDa}$ ) was revealed in $L b$. bulgaricus CNRZ 397 and Lb. lactis CNRZ 250 total extracts and a second major band (about $50 \mathrm{kDa}$ ) was 
found in the Lb. lactis extract. These data suggested the presence of two other proteins with a structural domain closely related to a PepQ region. It is noteworthy that, recently, a second $p e p Q$-like gene (orfZ) was detected in Lb. delbrueckii subspecies (Rantanen \& Palva, 1997). Under $\mathrm{pH}$-controlled conditions, orf $\mathrm{Z}$ was shown to be expressed at a very low level and to encode a $41 \mathrm{kDa}$ protein without any enzyme activity. It cannot be excluded that in Lb. bulgaricus CNRZ 397, a minor band with a similar molecular mass corresponds to an orf $Z$ gene product.

\section{DISCUSSION}

The PepQ enzyme we purified from $L b$, bulgaricus CNRZ 397 exhibits a narrow specificity towards X-Pro dipeptides, as expected for a prolidase. Nevertheless, analysis of PepQ from $L b$. bulgaricus revealed some significant differences as compared to prolidases already described in other micro-organisms. (i) It is the first time that a prokaryotic PepQ is described as a homodimer. (ii) In contrast to properties of prolidases from Lc. lactis subsp. cremoris AM2 and Lb. casei IFPL 731, we did not find any substrate inhibition (Booth et al., 1990; Fernandez-Espla et al., 1997). (iii) $\mathrm{Zn}^{2+}$ appeared to be essential to $L b$. bulgaricus PepQ activity, whereas an inhibition of enzyme activity by this divalent cation was described for PepQ from $L b$. casei IFLP 731 and, to a lesser extent, for PepQ from Lc. lactis subsp. cremoris H61 (Fernandez-Espla et al., 1997; Kaminogawa et al., 1984). Both enzymes were activated by other divalent cations such as $\mathrm{Mn}^{2+}$ or $\mathrm{Co}^{2+}$. (iv) PepQ proteins from lactobacilli differ from the lactococcal ones, since the latter are not recognized by antibodies raised against the Lb. bulgaricus enzyme.

General features shared by Lb. bulgaricus PepQ and other described prolidases are the inhibition by chelating and reducing agents, and the requirement of a divalent cation for the enzyme activity. The active site of human prolidase PepD, which requires $\mathrm{Mn}^{2+}$ as cofactor, has been extensively studied (King et al., 1989). In the proposed model, $\mathrm{Mn}^{2+}$ participates in the substrate positioning, and, in theory, this role could be effected by another divalent cation such as $\mathrm{Zn}^{2+}$. The specificity of prolidases towards different cations remains to be elucidated.

Peptide sequence analysis showed that PepQ does not belong to the large family of $\mathrm{Zn}$-metallopeptidases, but rather ranks among the M24 family of metallopeptidases, which also comprises PepMs and PepPs (Rawlings \& Barrett, 1995). Bazan et al. (1994) proposed that these enzymes, and also creatinases, share a common structure, in which five conserved residues bind two divalent cations. The metal ligands are located in the C-terminal part of the protein, and it was not surprising to find the highest sequence identity between $L b$. bulgaricus and other M24-family-related proteins in this region.
Lb. bulgaricus and Lb. lactis DSM 7290 pepQ genes have been expressed in E. coli (PepQ ${ }^{-} \mathrm{PepP}^{-}$strain), and the transcription level appeared significantly higher with the $L b$. bulgaricus promoter region. Some differences in the nucleotide sequences were observed between the intergenic regions of $L b$. lactis DSM 7290 and $L b$. bulgaricus, particularly in the RBS sequence of pepR1. The Lb. bulgaricus sequence could lead to a better binding of the $16 \mathrm{~S} \mathrm{rRNA}$ from $E$. coli, but the effect on the transcription of pepQ remains unclear (Shine $\&$ Dalgarno, 1974).

Peptidase regulation mechanisms have received little attention (reviewed by Gonzales \& Robert-Baudouy, 1996; Meijer et al., 1996). With regard to the proteolytic system of $L b$. bulgaricus CNRZ 397, we have previously shown that biosynthesis of two aminopeptidases (API and APIII) was subject to a regulatory mechanism related to the composition of culture medium (Atlan et al., 1989). Biosynthesis of the cell-surface proteinase (PrtB) was also dependent on the peptide concentration of the culture medium (Gilbert et al., 1997). In the present paper, a regulation mechanism for PepQ biosynthesis has been demonstrated for the first time. The mechanism involved is probably different from that controlling biosynthesis of PrtB, API and APIII, as well as lactococcal PepN and PepX, because PepQ biosynthesis is not dependent on extracellular peptide concentration (its substrate Leu-Pro included). A possible control could be ascribed to the presence of the close location of the promoter region of pepR1, including a well-conserved CRE sequence. The PepR1-deduced sequence is significantly similar to CcpA protein, which is involved in catabolite repression in Gram-positive bacteria. CcpA is known to bind specifically to CRE sequences via its helix-turn-helix domain, and consequently to repress the expression of catabolic operons displaying CRE sequences (reviewed by Saier et al., 1996). Such a CRE sequence was found in the pepR1$p e p Q$ intergenic region and might be the target of a transcription factor such as PepR 1 itself.

Experiments related to the potential role of PepR 1 in catabolite repression and/or pepQ transcription are now in progress. The biosynthetic regulation of two peptidases by components implicated in catabolite repression has already been described in Salmonella typhimurium (Conlin et al., 1994; Lombardo et al., 1997). The physiological significance of such a mechanism is not known. The identification of mechanisms involved in the biosynthetic regulation of peptidases will provide a better understanding of the role of these enzymes in the caseinolytic pathway of lactobacilli.

\section{ACKNOWLEDGEMENTS}

We are grateful to Dr Posno, Dr Hirashima and Professor Plapp for the gift of $L b$. casei ATCC $4646, L c$. lactis NCDO 763 and plasmid pMS2, respectively. We thank Professor Dorier for anti-PepQ antibodies, and Dr Deneroy for the Nterminal sequence of PepQ protein. This work was supported by research grants from the Centre National de la Recherche Scientifique (UMR CNRS 5534) and the Université Claude 
Bernard-Lyon I. F. Morel was a recipient of a fellowship from the Ministere de l'Enseignement Supérieur et de la Recherche.

\section{REFERENCES}

Atlan, D., Laloi, P. \& Portalier, R. (1989). Isolation and characterization of aminopeptidase-deficient Lactobacillus bulgaricus mutants. Appl Environ Microbiol 55, 1717-1723.

Atlan, D., Laloi, P. \& Portalier, R. (1990). X-Proline-dipeptidylaminopeptidase of Lactobacillus delbrueckii subsp. bulgaricus: characterization of the enzyme and isolation of deficient mutants. Appl Environ Microbiol 56, 2174-2179.

Atlan, D., Gilbert, C., Blanc, B. \& Portalier, R. (1994). Cloning, sequencing and characterization of the pepIP gene encoding a proline iminopeptidase from Lactobacillus delbrueckii subsp. bulgaricus CNRZ 397. Microbiology 140, 527-535.

Bazan, J., Weaver, L., Roderick, S., Huber, R. \& Matthews, B. (1994). Sequence and structure comparison suggest that methionine aminopeptidase, prolidase and aminopeptidase $\mathrm{P}$, and creatinase share a common fold. Proc Natl Acad Sci USA 91, 2473-2477.

Booth, M., Jennings, V., Fhaolain, I. \& O'Cuinn, G. (1990). Prolidase activity of Lactococcus lactis subsp. cremoris AM2: partial purification and characterization. J Dairy Res 57, 245-254.

Bradford, M. (1976). A rapid and sensitive method for the quantitation of microgram quantities of protein utilizing the principle of protein-dye binding. Anal Biochem 72, 248-254.

Chen, J. D. \& Morrison, D. (1987). Cloning of Streptococcus pneumoniae fragments in Escherichia coli requires vectors protected by strong transcriptional terminators. Gene 55, 179-187.

Conlin, C. A., Hakensson, K., Liljas, A. \& Miller, C. G. (1994). Cloning and nucleotide sequence of the cyclic AMP receptor protein-regulated Salmonella typhimurium pepE gene and crytallization of its product, an $\alpha$-aspartyl dipeptidase. J Bacteriol 176, 166-172.

Edman, P. \& Begg, G. (1967). A protein sequenator. Eur J Biochem 1, 80-91.

Fernandez-Espla, M. D., Martin-Hernandez, M. C. \& Fox, P. F. (1997). Purification and characterization of a prolidase from Lactobacillus casei subsp. casei IFPL 731. Appl Environ Microbiol 63, 314-316.

Fujita, N., Mori, H., Yura, T. \& Ishihama, A. (1994). Systematic sequencing of the Escherichia coli genome: analysis of the 2.4-4.1 min (110917-193643 bp) region. Nucleic Acids Res 22, 1637-1639.

Gilbert, C., Atlan, D., Blanc, B. \& Portalier, R. (1994). Proline iminopeptidase from Lactobacillus delbrueckii subsp. bulgaricus CNRZ 397: purification and characterization. Microbiology 140, $537-542$.

Gilbert, C., Atlan, D., Blanc, B., Portalier, R., Germond, J.-E., Lapierre, L. \& Mollet, B. (1996). A new cell surface proteinase: sequencing and analysis of the prtB gene from Lactobacillus delbrueckii subsp. bulgaricus. J Bacteriol 178, 3059-3065.

Gilbert, C., Blanc, B., Frot-Coutaz, J., Portalier, R. \& Atlan, D. (1997). Comparison of cell surface proteinase activities in Lactobacillus genus. J Dairy Res 64, 561-571.

Gonzales, T. \& Robert-Baudouy, J. (1996). Bacterial aminopeptidases: properties and functions. FEMS Microbiol Rev 18, 319-344.

Harlow, E. \& Lane, D. (1988). Antibodies. a Laboratory Manual. Cold Spring Harbor, NY: Cold Spring Harbor Laboratory.
Kaminogawa, S., Azuma, N., Hwang, I.-K., Suzuki, Y. \& Yamauchi, K. (1984). Isolation and characterization of a prolidase from Streptococcus cremoris H61. Agric Biol Chem 48, 3035-3040.

King, G. F., Crossley, M. J. \& Kuchel, P. W. (1989). Inhibition and active-site modelling of prolidase. Eur J Biochem 180, 377-384.

Laemmli, U. (1970). Cleavage of structural proteins during the assembly of the head of bacteriophage T4. Nature 227, 680-685.

Lombardo, M., Lee, A., Knox, T. \& Miller, C. (1997). Regulation of the Salmonella typhimurium pepT gene by cyclic AMP receptor protein (CRP) and FNR acting at a hybrid CRP-FNR site. J Bacteriol 179, 1909-1917.

Lorence, M. C. \& Rupert, C. S. (1983). Convenient construction of recA deletion derivatives of Escherichia coli. J Bacteriol 156, 458-459.

de Man, J., Rogosa, M. \& Sharpe, E. (1960). A medium for the cultivation of lactobacilli. J Appl Bacteriol 23, 130-135.

Matern, H., Klein, J., Henrich, B. \& Plapp, R. (1994). Determination and comparison of Lactobacillus delbrueckii ssp. lactis DSM7290 promoter sequence. FEMS Microbiol Lett 122, 121-128.

Matos, J., Nardi, M., Kumara, H. \& Monnet, v. (1998). Genetic characterization of pepP, which encodes an aminopeptidase $P$ whose deficiency does not affect Lactococcus lactis growth in milk, unlike deficiency of the X-prolyl dipeptidyl aminopeptidase. Appl Environ Microbiol 64, 4591-4595.

Meijer, W., Marrug, J. \& Hugenholtz, J. (1996). Regulation of proteolytic activity in Lactococcus lactis. Appl Environ Microbiol 62, 156-161.

Miller, J. (1972). Experiments in Molecular Genetics. Cold Spring Harbor, NY : Cold Spring Harbor Laboratory.

Miller, C. \& Schwartz, G. (1978). Peptidase-deficient mutants of Escherichia coli. J Bacteriol 135, 603-611.

Monedero, V., Gosalbes, M. J. \& Perez-Martinez, G. (1997). Catabolite repression in Lactobacillus casei ATCC393 is mediated by CcpA. J Bacteriol 179, 6657-6664.

Nakahigashi, K. \& Inokuchi, H. (1990). Nucleotide sequence between the fadB gene and the $r r n A$ operon from Escherichia coli. Nucleic Acids Res 18, 6439.

Nakamura, K., Nakamura, A., Takamatsu, H., Yoshikawa, H. \& Yamane, K. (1990). Cloning and characterizing of a Bacillus subtilis gene homologous to E. coli secY.J Biochem 107, 603-607.

Ochman, H., Medhora, M., Garza, D. \& Hartl, D. (1990). Amplification of flanking sequences by inverse PCR. In PCR Protocols: a Guide to Methods and Applications, pp. 219-227. Edited by M. Innis, D. Gelfand, J. Sninsky \& T. White. San Diego, CA : Academic Press.

Rantanen, T. \& Palva, A. (1997). Lactobacilli carry cryptic genes encoding peptidase-related proteins: characterization of a prolidase gene $(p e p Q)$ and a related cryptic gene (orf $Z$ ) from Lactobacillus delbrueckii subsp. bulgaricus. Microbiology 143, 3899-3905.

Rawlings, N. \& Barrett, A. (1995). Evolutionary of metallopeptidases. In Metallopeptidases, pp. 183-228. Edited by A. Barrett. San Diego, CA: Academic Press.

Roderick, S. \& Matthews, B. (1993). Structure of the cobaltdependent methionine aminopeptidase from Escherichia coli: a new type of proteolytic enzyme. Biochemistry 32, 3907-3912.

Saier, M., Chauvaux, S., Cook, G., Deutscher, J., Paulsen, I., Reizer, J. \& Ye, J. J. (1996). Catabolite repression and inducer control in Gram-positive bacteria. Microbiology 142, 217-230. 
Sambrook, J., Fritsch, E. \& Maniatis, T. (1989). Molecular Cloning: a Laboratory Manual, 2nd edn. Cold Spring Harbor, NY: Cold Spring Harbor Laboratory.

Shine, J. \& Dalgarno, L. (1974). The 3 '-terminal sequence of Escherichia coli $16 \mathrm{~S}$ rRNA: complementary to nonsense triplets and ribosome binding site. Proc Natl Acad Sci USA 71, 1342-1346.

Stoker, N., Fairweather, N. \& Spratt, B. (1982). Versatile lowcopy-number plasmid vectors for cloning in Escherichia coli. Gene 18, 335-341.

Stucky, K., Klein, J., Schüller, A., Matern, H., Henrich, B. \& Plapp, R. (1995). Cloning and DNA sequence analysis of $p e p Q$, a prolidase gene from Lactobacillus delbrueckii subsp. lactis DSM7290 and partial characterization of its product. Mol Gen Genet 247, 494-50.

Stucky, K., Schick, J., Klein, J., Henrich, B. \& Plapp, R. (1996). Characterization of pepR1, a gene coding for a potential transcriptional regulator of Lactobacillus delbrueckii subsp. lactis DSM7290. FEMS Microbiol Lett 136, 63-69.
Tanoue, A., Endo, F. \& Matsuda, I. (1990). Structural organization of the gene for human prolidase (peptidase D) and demonstration of a partial gene deletion in a patient with prolidase deficiency. $J$ Biol Chem 265, 11306-11311.

Terzaghi, B. \& Sandine, W. (1975). Improved medium for lactic streptococci and their bacteriophages. Appl Environ Microbiol 29, 807-813.

Yanisch-Perron, C., Vieira, J. \& Messing, J. (1985). Improved M13 phage cloning vectors and host strains: nucleotide sequences of the M13mp18 and pUC19 vectors. Gene 33, 103-119.

Yaron, A. \& Mlynar, D. (1968). Aminopeptidase P. Biochem Biophys Res Commun 32, 658-663.

Yoshimoto, T., Tone, H., Honda, T., Osatomi, K., Kobayashi, R. \& Tsuru, D. (1989). Sequencing and high expression of aminopeptidase P from Escherichia coli HB101. J Biochem 105, 412-416.

Received 19 June 1998; revised 28 September 1998; accepted 5 October 1998. 